\title{
Effect of Growth Regulators on Yield and Quality of Sweet Orange (Citrus sinensis L. Osbeck.) cv. Jaffa
}

\author{
Sweety*, G.S. Rana and G. Chandramohan Reddy \\ Department of Horticulture, College of Agriculture, CCS Haryana Agricultural University, \\ Hisar-125004, Haryana, India \\ *Corresponding author
}

\begin{abstract}
A B S T R A C T
Keywords

Growth regulators,

Yield, Quality

Citrus sinensis

Article Info

Accepted:

20 November 2018

Available Online:

10 December 2018

An experiment was conducted to study the effect of different growth regulators on yield and quality of sweet orange cv. Jaffa at Research Orchard of Department of Horticulture, Chaudhary Charan Singh Haryana Agricultural University, Hisar, India during the year 2015-16. Plants were treated with GA3, 2,4-D and NAA in different concentrations was sprayed twice, i.e., in last week of March and first week of July and control (distilled water) yield and physico-chemical changes was observed at regular intervals. The experimental design was randomized block design (RBD) and each treatment was replicated four times. Experimental findings revealed that, among the growth regulators NAA 20 ppm recorded with highest number of fruits per plant and fruit yield per plant than other treatments. It was observed that quality parameters such as TSS ( ${ }^{\circ}$ Brix) (9.87), TSS to acid ratio (15.10), Ascorbic acid $(51.44 \mathrm{mg} / 100 \mathrm{ml}$ ) was found to be more in 2,4D- $15 \mathrm{ppm}$ followed by NAA- $30 \mathrm{ppm}$. It proved the effectiveness of growth regulators in increasing yield and quality of sweet orange.
\end{abstract}

\section{Introduction}

Citrus is one of the most important fruit tree species in the world as well as India, as the fruits are a valuable source of nutrients, vitamins and other antioxidant compounds Sweet orange (Citrus sinensis Osbeck.) has been reported to be originated in Southern China and migrated to India during thirteenth century. Sweet orange is the second largest citrus fruit cultivated in the country. It is more convenient to grow under dry arid conditions coupled with distinct winter and summer season with low rainfall. Many varieties of sweet orange have been introduced in India, while only few are prolific bearer having good quality. Currently, exotic cultivars like Jaffa, Blood Red and Pineapple are performing well in Punjab, Haryana and Rajasthan. Among exotic cultivars, Jaffa is an important commercial cultivar of sweet orange. It is one of the mid-season cultivars of sweet orange with wider adaptability.

Fruit drop in citrus crops is a serious problem and a limiting factor for obtaining increased fruit yield. In citrus, there is heavy flowering, and initially, fruit set is high but continuous 
dropping of fruits at various stages of fruit growth results in considerable reduction in total yield. Citrus trees produce a very large number of flowers, 30-150 times more than they can bear the fruits Huchche et al., 2012). Due to heavy production of flowers, a high post setting drop of fruit lets is occurred and growers are not much concern about this drop (Huchche et al., 2012).

It is estimated that the fruit drop in citrus cultivars commencing from August continues up to the end of December. In sweet orange cultivars, the total estimated drop of 57.2, 47.6, 48.5, 48.6, 54.9 and 34.5 percent in cultivar Mosambi, Pineapple, Hamlin, Jaffa, Blood Red and Valencia, respectively was recorded by Jawanda et al., (1972).

The use of plant growth regulators has become an important component in the field of citriculture because of the wide range of potential roles they play in increasing the productivity of crop per unit area.

The plant growth regulating compounds actively regulate the growth and development by regulation of the endogenous processes and there exogenous applications have been exploited for modifying the growth response. Hence, the present study was undertaken, with the following objective, to determine the effect of growth regulators on yield and quality of sweet orange cultivar Jaffa.

\section{Materials and Methods}

A field experiment entitled effect of plant growth regulators on sweet orange was carried out in the year 2015-16 at the orchard of Department of Horticulture, CCS Haryana Agricultural University, Hisar, Haryana. The experiment was laid out in randomized block design with 10 treatments, viz. (T1) GA3 10 ppm, (T2) GA3 20 ppm, (T3) GA3 30 ppm, (T4) 2,4-D 5ppm, (T5) 2,4-D 10 ppm, (T6)
2,4-D 15 ppm, (T7) NAA 20 ppm (T8) NAA 30 ppm (T9) NAA 40 ppm and (T10) (control) i.e. water spray.

There were two spray schedules i.e. last week of March and first week of July).Sixteen years old uniformly grown trees spaced at $6 \mathrm{~m} \times 6 \mathrm{~m}$ were selected for present study. They were kept under uniform conditions of orchard management during the study period where all the agronomic practices were carried out as per package of practices. Spraying was done as per the treatment early in the morning. Each tree was sprayed heavily by taking care to wet the complete tree. It was fully ensured that all the sides of the tree were quenched completely by the spraying solutions.

The observations of yield parameters (Number of fruits per tree, Fruit weight and Fruit yield) are taken by harvesting fruits at once and number of fruits per plant was recorded and weigh are taken on electronic balance; physicochemical composition of fruit such as number of seed per fruit, TSS, Acidity, Ascorbic acid are also recorded as protocol. All data were subjected to statistical analysis as per methods advocated by.

\section{Results and Discussion}

\section{Yield parameters}

The data presented in Table 1 shown that the number of fruits per tree was significantly influenced by different concentrations of GA3, 2, 4-D and NAA. The highest number of fruits per tree (246.67), maximum fruit yield (44.32 $\mathrm{kg} / \mathrm{plant}$ ) and maximum fruit retention $(86.22 \%)$ was recorded from the plant sprayed with NAA $20 \mathrm{ppm}$ while the minimum number of fruits per plant was recorded under control treatment respectively. while the other parameters of fruit like fruit weight $(180.00 \mathrm{~g})$ were obtained highest with foliar application of GA3 30 ppm than other treatments. 
Table.1 Effect of growth regulators on yield parameters in sweet orange cv. Jaffa

\begin{tabular}{|c|c|c|c|c|}
\hline Treatments & $\begin{array}{c}\text { Number of } \\
\text { seeds per fruit }\end{array}$ & $\begin{array}{l}\text { Fruit yield } \\
\text { (kg/plant) }\end{array}$ & Fruit weight (g) & $\begin{array}{l}\text { Percent fruit } \\
\text { retention }\end{array}$ \\
\hline $\mathrm{T}_{1}: \mathbf{G A}_{3^{-}} 10 \mathrm{ppm}$ & 7.33 & 33.23 & 178.00 & 80.36 \\
\hline$T_{2}: G_{3}-20 \mathrm{ppm}$ & 6.00 & 30.97 & 179.33 & 77.04 \\
\hline $\mathrm{T}_{3}: \mathrm{GA}_{3^{-}} 30 \mathrm{ppm}$ & 5.00 & 29.76 & 180.00 & 74.63 \\
\hline $\mathrm{T}_{4}:$ 2,4-D- 5ppm & 8.87 & 40.16 & 170.67 & 83.54 \\
\hline $\begin{array}{l}\mathrm{T}_{5}: 2,4-\mathrm{D}-10 \\
\text { ppm }\end{array}$ & 6.67 & 41.71 & 173.33 & 83.78 \\
\hline $\begin{array}{l}\mathrm{T}_{6}: 2,4-\mathrm{D}-15 \\
\text { ppm }\end{array}$ & 7.67 & 34.32 & 169.33 & 82.16 \\
\hline $\begin{array}{l}\mathrm{T}_{7}: \mathrm{NAA}-20 \\
\text { ppm }\end{array}$ & 8.67 & 44.32 & 179.67 & 86.22 \\
\hline $\begin{array}{l}\text { T8: NAA- } 30 \\
\text { ppm }\end{array}$ & 9.33 & 40.68 & 178.67 & 82.85 \\
\hline $\begin{array}{l}\text { T9: NAA- } 40 \\
\text { ppm }\end{array}$ & 11.33 & 26.46 & 174.67 & 76.35 \\
\hline $\begin{array}{l}\mathrm{T}_{10} \text { : Control- } \\
\text { water spray }\end{array}$ & 9.67 & 26.63 & 163.33 & 70.38 \\
\hline $\begin{array}{l}\text { C.D. at } 5 \% \text { level } \\
\text { of significance }\end{array}$ & $\mathbf{N A}$ & 2.67 & 4.09 & 2.51 \\
\hline
\end{tabular}

Table.2 Effect of growth regulators on quality parametersin sweet orange cv. Jaffa

\begin{tabular}{|c|c|c|c|c|}
\hline Treatments & TSS ( ${ }^{\circ}$ Brix) & Acidity (\%) & $\begin{array}{l}\text { TSS to acid } \\
\text { ratio }\end{array}$ & $\begin{array}{l}\text { Ascorbic acid } \\
(\mathrm{mg} / 100 \mathrm{ml})\end{array}$ \\
\hline $\mathrm{T}_{1}: \mathrm{GA}_{3^{-}} \mathbf{1 0} \mathrm{ppm}$ & 8.87 & 0.75 & 11.77 & 45.84 \\
\hline $\mathrm{T}_{2}: \mathrm{GA}_{3}-20 \mathrm{ppm}$ & 8.40 & 0.77 & 10.96 & 43.45 \\
\hline $\mathrm{T}_{3}: \mathrm{GA}_{3}-30 \mathrm{ppm}$ & 8.17 & 0.78 & 10.42 & 50.47 \\
\hline $\mathrm{T}_{4}:$ 2,4-D- 5ppm & 8.87 & 0.73 & 12.14 & 44.53 \\
\hline $\begin{array}{l}\text { T5: 2,4-D- } 10 \\
\text { ppm }\end{array}$ & 9.67 & 0.68 & 14.15 & 46.39 \\
\hline $\begin{array}{l}\text { T}_{6}: 2,4-D-15 \\
\text { ppm }\end{array}$ & 9.87 & 0.65 & 15.10 & 51.44 \\
\hline $\begin{array}{l}\text { T }_{7}: \text { NAA- } 20 \\
\text { ppm }\end{array}$ & 9.30 & 0.72 & 12.92 & 45.43 \\
\hline $\begin{array}{l}\text { T8: NAA- } 30 \\
\text { ppm }\end{array}$ & 9.83 & 0.67 & 14.68 & 47.65 \\
\hline $\begin{array}{l}\text { T9: NAA- } 40 \\
\text { ppm }\end{array}$ & 9.33 & 0.71 & 13.08 & 49.16 \\
\hline $\begin{array}{l}\mathrm{T}_{10} \text { : Control- } \\
\text { water spray } \\
\end{array}$ & 8.07 & 0.79 & 10.17 & 42.25 \\
\hline $\begin{array}{l}\text { C.D. at } 5 \% \text { level } \\
\text { of significance }\end{array}$ & 0.31 & N.S. & 0.63 & 0.94 \\
\hline
\end{tabular}


The maximum number of fruits per plant with NAA $20 \mathrm{ppm}$ might be attributed to less dropping of flowers and fruits, as the application of growth regulators made up the deficiency of endogenous auxin, which prevented formation of abscission layer possibly through the inhibition of enzymatic activity at higher temperature. The results of present investigation are in conformation with the findings of (Greenberg et al., 2006) who observed that 2,4-D $40 \mathrm{mg} / \mathrm{l}$, NAA $300 \mathrm{mg} / \mathrm{l}$ and 3,5,6-TPA $15 \mathrm{mg} / \mathrm{l}$ accumulate 150 fruits per plant, respectively. (Nawaz et al., 2008) who reported that the number of fruits per plant increased significantly with the application of 2,4-D, $\mathrm{GA}_{3}$ and NAA during last week of November in Kinnow mandarin, (Hussain et al., 2011) who observed the highest number of fruits per plant in treatment $5 \mathrm{mg} / \mathrm{l} \mathrm{GA}_{3}$ (682.33)followed by $10 \mathrm{mg} / \mathrm{l}$ 2,4$\mathrm{D}$ and $5 \mathrm{mg} / \mathrm{l} \mathrm{NAA}$ with 659.66 and 647.66 fruits per plant, respectively and (Saleem et al., 2013, Patel et al., 2013) who observed that the highest number of fruits per tree was recorded with treatment NAA200 mg/l (1020.33). (Tiwanja et al., 2007, Thind et al., 2008) also concluded same results in their investigation

\section{Quality parameters}

The results obtained from the present investigation in Table 2 reveal that the maximum TSS $\left(9.87^{\circ}\right.$ Brix $)$, TSS to acid ratio (15.10), Ascorbic acid $(51.44 \mathrm{mg} / 100 \mathrm{ml})$ was recorded in fruits harvested from plants sprayed with 2,4-D 15 ppm followed by NAA 30 ppm than other treatments.

The increased TSS due to the spray of 2,4-D and NAA might be because of the increased translocation of sugars from source to the sink. The findings are also supported by Ahmad et al., (2008) who observed the maximum TSS in fruits taken from the trees sprayed with 2,4-D 30 ppm (12.03\%) followed by 2,4-D $20 \mathrm{ppm}$ and NAA $15 \mathrm{ppm}$ with the values of 11.93 and $11.79 \%$, respectively.

Dhaliwal et al., (2009) who revealed the highest TSS in fruits taken from the trees sprayed with carbendazim 50WP $0.1 \%+2,4-$ D 10 ppm (11.4\%) in Kinnow mandarin. Hussain et al., (2011) and Tamer et al., (2012) who observed the maximum TSS in fruits taken from the trees sprayed with NAA $10 \mathrm{mg} / \mathrm{l}$ followed by NAA $20 \mathrm{mg} / \mathrm{l}$ and 2,4-D $30 \mathrm{mg} / \mathrm{l}$ respectively. Prasad et al., (2013) who recorded the maximum TSS in fruits taken from the trees supplied with Urea + $\mathrm{ZnSO}_{4}+2,4-\mathrm{D}\left(15.4^{\circ}\right.$ Brix $)$ and Shweta and Misra (2015) observed the maximum TSS in fruits harvested from trees sprayed with NAA20 ppm (38.00\%).Kaur et al., (2000) who noticed an increase in vitamin $\mathrm{C}$ content over control with the application of 2,4-D 20 ppm in Kinnow mandarin.

In conclusion, thus the results of this study suggested that growth regulators have a great potential to affect yield and quality of sweet orange. It is concluded that NAA had positive effect on yield, while $\mathrm{GA}_{3}$ and 2,4-D had significant impact on quality parameters. Thus, the maximum percent fruit retention and fruit yield per plant was observed when the plants were sprayed with NAA 20 ppm, while the TSS, TSS to acid ratio and ascorbic acid were recorded maximum and acidity minimum with foliar application of 2,4-D 15 ppm at pin head stage and in the middle of fruit growth in sweet orange cv. Jaffa. Therefore, these can be utilized for sustainable and higher fruit production and the fruit drop can be reduced to a great extent.

\section{References}

Ahmad, S., Nawaz, M.A., Ahmad, W. and Khan, M.M. 2008. Role of growth regulators on pre-harvest fruit drop, yield and quality in kinnow mandarin. Pakistan 
Journal of Botany. 40(5): 1971-1981.

Dhaliwal, H.S., Rattanpal, H.S., Anita and Arora, N. 2009. Integrated control of fruit drop in Kinnow Mandarin. Journal of Res Punjab Agriculture University. 46(3\&4): 163-65.

Greenberg, J., Kaplan, I., Fainzack, M., Egozi, Y. and Giladi, B. 2006. Effects of auxins sprays on yield, fruit size, fruit splitting and the incidence of creasing of Nova Mandarin. Acta Horticulturae, 727.

Huchche, A. D., Patil, P., and Panchbhai, D. M. 2012 Recent advances in physiology of flowering in citrus. Souvenier and Abstracts of National Dialogue on Citrus Improvement, production and utilization, 27th - 29th February, 2012, at NRC Citrus, Nagpur, pp. 103-29.

Hussain, Z., Sivla, J.A.T.D., Nawaz, M.A., Afzal, M., Ahmed, W., Ashraf, M., Akhtar, N., Shazad, S.M. and Ullah, H., 2011. Exogenous application of 2,4-D, $\mathrm{GA}_{3}$, NAA at flowering improves yield and quality of Kinnow Mandarin (Citrus reticulata Blanco). The Asian and Australasian Journal of Plant Science and Biotechnology, 5(1): 17-21.

Jawanda, J.S., Sinha, M.K. and Uppal, D.K. 1972. Studies on nature and periodicity of pre-harvest fruit drop in sweet orange. Indian Journal of Horticulture. 29: 269276.

Kaur, N., Monga, P.K., Thatai, S.K. and Vij, V.K., 2000. Effect of growth regulators on periodical fruit drop in Kinnow mandarin. Haryana Journal of Horticultural Sciences. 29(1\&2): 39-41.

Panse, V. G and Sukhatme, P.V. 1985.Statistical methods for agricultural workers. ICAR, New Delhi.
Patel, H.C.,Jagtap, V.M. and Nehete, D.S. 2013. Effect of foliar application of plant growth regulators and micronutrients on growth and yield of Acid lime cv. Kagzi (Citrus aurantifolia Swingle). BIOINFOLET. 10(2A): 469-472.

Prasad, H., Prasad, D., Bhan, C., Bairwa, S.K., Babu, S. and Pal, S., 2013. Effect of foliar application of urea, zinc sulphate, and 2,4-D on kinnow mandarin. Journal of Progressive Agriculture. 4(1):148-153.

Saleem, A.B., Malik, A.U., Perevez, A.M., Khan, A. and Khan, M. 2008. Spring application of growth regulators affects fruit quality of 'Blood Red' sweet orange. Pakistan Journal of Botany. 40(3): 10131023.

Shweta, U. and Misra, K.K., 2015. Effect of plant growth regulators on fruit drop and quality of Baelunder Taraiconditions of Uttarakhand. Indian Journal of Horticulture.71(1): 126-129.

Tamer, S., Yıldırıma, B., lua, T.Y.I., Ncesua, M.I., lub, M.C.K. and Imena, B.C. 2012. Effects of 2,4-DP (2,4dichlorophenoxypropionic acid) plant growth regulator on fruit size and yield of Valencia oranges (Citrus sinensis Osbeck.). New Zealand Journal of Crop and Horticultural Science.40(1): 55-64.

Thind, S.K. and Kumar, A. 2008. Integrated management of fruit drop in Kinnow mandarin. Indian Journal of Horticulture. 65(4): 497-499.

Tiwana, T.S. and Bajwa, G.S., 2007. Effect of plant growth regulators and fungicides on pre-harvest fruit drop and yield of Kinnow mandarin. South Indian Horticulture. 55(1-6): 264-269.

\section{How to cite this article:}

Sweety, G.S. Rana and Chandramohan Reddy, G. 2018. Effect of Growth Regulators on Yield and Quality of Sweet Orange (Citrus sinensis L. Osbeck.) cv. Jaffa. Int.J.Curr.Microbiol.App.Sci. 7(12): 2963-2967. doi: https://doi.org/10.20546/ijcmas.2018.712.338 